\title{
Dimethyl Ether a Rural Fuel from Water and Carbon Dioxide
}

\author{
Johann Gruber-Schmidt* \\ Technical University Vienna, Australia
}

Submission: February 1, 2017; Published: February 17, 2017

*Corresponding author: Johann Gruber-Schmidt, Technical University Vienna, Theresiengasse 47, A 1180 Vienna, Australia, Email: johann.gruber-schmidt@chello.at

\section{Opinion}

DME known as dimethyl ether [1], is a well known chemical substance, the simplest ether, with the chemical structure $\mathrm{CH}_{3}$ $\mathrm{O}-\mathrm{CH}_{3}$, consisting of one oxygen atom, two carbon atoms, and six hydrogen atoms. If we us Dimethyl ether as fuel, we recognize, that this fuel brings in one oxygen atom and has six hydrogen atoms. If we compare with methanol $\left(\mathrm{CH}_{3}-\mathrm{OH}\right)$, which has only four hydrogen atoms, dimethyl ether as simplest ether can also be seen as hydrogen carrier. The thermodynamic properties of Dimethyl ether, show that dimethyl ether is liquid at room temperature $\mathrm{T}=25^{\circ} \mathrm{C}$ and a pressure of $\mathrm{p}=6$ bar. [1]. It is well known that dimethyl ether can be used as an substitute of fossil Diesel fuel [2], as a synthetic formed Diesel substitute, with highly advanced combustion properties and very low emissions in carbon monoxide (CO), dust and soot and nitrogen oxide $\left(\mathrm{NO}_{2}\right.$ ). It easy to handle with the well known LPG (liquid propane gas) technology and can be easily and cheap implemented into heavy Diesel engines [2]. The application of dimethyl ether is wide: transportation [2-5], agriculture [6,7], civil and rural hotel sector.

One pathway to produce dimethyl ether from biogenic waste is using steam gasification [5,7] or classic gasification by fixed bed reactors [5,7]. The weak gas consists of the main components carbon monoxide (CO), hydrogen (H2) and small amount of methane $\left(\mathrm{CH}_{4}\right)$, carbon dioxide (CO2) and tar. A representative gas mixture is e.g. 32 vol\% CO, 27 vol\% $\mathrm{H} 2,12$ vol $\% \mathrm{CO}_{2}, 1$ vol\% $\mathrm{CH} 4,3$ vol\% tar. If we look at the concentration of carbon monoxide (CO) and hydrogen $\left(\mathrm{H}_{2}\right)$ we recognize that the molar concentration is near by the fraction $1: 1$. This enables the direct conversion of carbon monoxide (CO) and hydrogen $\left(\mathrm{H}_{2}\right)$ to Dimethyl ether by $\mathrm{CO}+\mathrm{H}_{2} \mathrm{O}=>\mathrm{CO}_{2}+\mathrm{H} 2(1)$, $2 \mathrm{CO}+4 \mathrm{H} 2=>2 \mathrm{CH}_{3} \mathrm{OH}(2), 2 \mathrm{CH} 3 \mathrm{OH}=>+\mathrm{CH}_{3}-\mathrm{O}-\mathrm{CH}_{3}+\mathrm{H}_{2} \mathrm{O}(3)$. The sum reaction is given by $3 \mathrm{CO}+3 \mathrm{H}_{2}=>\mathrm{CH}_{3}-\mathrm{O}-\mathrm{CH}_{3}+\mathrm{CO}_{2}$. What we learn from this reaction pathway: the direct synthesis from carbon monoxide (CO) and hydrogen $\left(\mathrm{H}_{2}\right)$ produce dimethyl ether and carbon dioxide. The direct synthesis is supported by the catalyst CuO-Zno-Al2O3 for the conversion to methanol $\left(\mathrm{CH}_{3} \mathrm{OH}\right)$ and the dehydration of methanol $\left(\mathrm{CH}_{3} \mathrm{OH}\right)$ to dimethyl ether by the catalyst HZSM-5 (zeolith). The combination of both reaction leads to carbon dioxide production during the conversion process [8]. The existence of carbon dioxide $\left(\mathrm{CO}_{2}\right)$ leads to a reduction in the conversion rate to dimethyl ether. Beside dimethyl ether, Methanol, water and carbon dioxide will be produced. So the carbon dioxide concentration of the input gas should be very low, in common lower than 1 vol\%. Tar has to be removed and lowered to $100 \mathrm{ppm}$ [9]. The conversion rate depends on the pressure and temperature in the direct synthesis reactor and the concentration mixture of the catalysts $\mathrm{CuO}$ $\mathrm{ZnO}-\mathrm{Al}_{2} \mathrm{O}_{3}$ (conversion to methanol) and HSZM-5 (dehydration zeolite). The pressure range is about 30 bar up to 70 bar, the temperature range is about $200^{\circ} \mathrm{C}$ up to $300^{\circ} \mathrm{C}$. The maximum conversion rate to dimethyl ether reaches a value of about $40 \%$, and 5\% methanol and 5\% water, and the rest of carbon monoxide (CO), hydrogen $\left(\mathrm{H}_{2}\right)$ and carbon dioxide $\left(\mathrm{CO}_{2}\right)$ [5]. Cooling down the output gas of the reactor leads to a condensate consisting of dimethyl ether, water and methanol. Besides dimethyl ether we gain, water $\left(\mathrm{H}_{2} \mathrm{O}\right)$, carbon dioxide $\left(\mathrm{CO}_{2}\right)$ and methanol $\left(\mathrm{CH}_{3} \mathrm{OH}\right)$. Methanol can be converted to dimethyl ether by dehydration $2 \mathrm{CH}_{3} \mathrm{OH}=>\mathrm{CH}_{3}-\mathrm{O}-\mathrm{CH}_{3}+\mathrm{H} 2 \mathrm{O}$ and water. Again we gain water. We can conclude we gain from the gas mixture from the gasification dimethyl ether $\left(\mathrm{CH}_{3}-\mathrm{O}-\mathrm{CH}_{3}\right)$ water $\left(\mathrm{H}_{2} \mathrm{O}\right)$ and carbon dioxide $\left(\mathrm{CO}_{2}\right)$. The other gas components like hydrogen $\left(\mathrm{H}_{2}\right)$ and carbon monoxide ( $\mathrm{CO}$ ) can be recycled by leading back to reactor again.

The second pathway to produce dimethyl ether is the conversion of carbon dioxide $\left(\mathrm{CO}_{2}\right)$ and hydrogen $(\mathrm{H} 2)$ by $2 \mathrm{CO}_{2}+6 \mathrm{H}_{2} \Rightarrow 2 \mathrm{CH}_{3} \mathrm{OH}+2 \mathrm{H}_{2} \mathrm{O}(1), 2 \mathrm{CH}_{3} \mathrm{OH} \Rightarrow \mathrm{CH}_{3}-\mathrm{O}-\mathrm{CH} 3+$ $3 \mathrm{H} 2 \mathrm{O}$ (2) and the sum reaction $2 \mathrm{CO} 2+6 \mathrm{H} 2=>\mathrm{CH}_{3}-\mathrm{O}-\mathrm{CH} 3+$ $3 \mathrm{H} 2 \mathrm{O}$. The direct conversion of carbon dioxide (CO2) and hydrogen $\left(\mathrm{H}_{2}\right)$ to dimethyl ether leads to water $\left(\mathrm{H}_{2} \mathrm{O}\right)$. For the optimum on conversion a molar gas mixture of carbon dioxide 
$\left(\mathrm{CO}_{2}\right)$ and Hydrogen $\left(\mathrm{H}_{2}\right)$ from 1:3 is needed. The conversion rate depends on the pressure and temperature in the reactor and the concentration mixture of the catalysts $\mathrm{CuO}-\mathrm{ZnO}-\mathrm{ZrO} 2$ (conversion to methanol) and HSZM-5 (dehydration zeolite). The pressure range is about 30 bar up to 70 bar, the temperature range is about $200^{\circ} \mathrm{C}$ up to $300^{\circ} \mathrm{C}$. The maximum conversion rate to dimethyl ether reaches a value of about $40 \%$, and $5 \%$ methanol and $5 \%$ water, and the rest of carbon dioxide $\left(\mathrm{CO}_{2}\right)$, hydrogen $\left(\mathrm{H}_{2}\right)$. Cooling down the output gas of the reactor leads to a condensate consisting on Dimethyl ether, water and methanol. Besides Dimethyl ether we gain, water $\left(\mathrm{H}_{2} \mathrm{O}\right)$, carbon dioxide $\left(\mathrm{CO}_{2)}\right.$ and methanol $\left(\mathrm{CH}_{3} \mathrm{OH}\right)$. Methanol can be converted to dimethyl ether by dehydration $2 \mathrm{CH}_{3} \mathrm{OH}=>\mathrm{CH}_{3}-\mathrm{O}-\mathrm{CH}_{3}+\mathrm{H}_{2} \mathrm{O}$ and water. Again we gain water. We can conclude we gain from the gas mixture from the gasification dimethyl ether $\left(\mathrm{CH}_{3}-\mathrm{O}-\mathrm{CH}_{3}\right)$ water (H2O).

If we compare the both pathways we recognize: (1) the conversion of biomass over gasification leads to dimethyl ether, water and carbon dioxide $\left(\mathrm{CO}_{2}\right)$. The conversion of carbon dioxide $\left(\mathrm{CO}_{2}\right)$ and hydrogen $\left(\mathrm{H}_{2}\right)$ leads to Dimethyl ether and water $\left(\mathrm{H}_{2} \mathrm{O}\right)$. The combination of both pathways lead to a reduction of carbon dioxide and water. Water has to be split up into hydrogen (H2) and oxygen $\left(\mathrm{O}_{2}\right)$ by the well known electrolysis. The pathway with conversion on biomass to dimethyl ether is limited. Biomass is the limiting substrate, influenced by the growth and concentration. Therefore biomass should be reduced to recycling biogenic waste. The limitation to biogenic waste leads to a limitation in the production and conversion to Dimethyl ether. To up scale the process we have to combine with the pathway converting carbon dioxide $\left(\mathrm{CO}_{2}\right)$ and hydrogen $\left(\mathrm{H}_{2}\right)$ to Dimethyl ether. Hydrogen is gained by water splitting using electrolysis to hydrogen $\left(\mathrm{H}_{2}\right)$ and oxygen (O2).

The energy provided by biomass is limited $[7,8]$, so in up scaling the conversion of carbon dioxide ( $\mathrm{CO} 2)$ and water $(\mathrm{H} 2 \mathrm{O})$ to dimethyl ether, additional energy is needed. Energy as electric energy used for the electric driven components and the main part for water or steam electrolysis. For a first estimation the chemical reaction equation $\mathrm{H}_{2} \mathrm{O}=>\mathrm{H} 2+1 / 2 \mathrm{O}_{2}$ leads to the result that we need $5 \mathrm{kWh}$ electric energy for $1 \mathrm{Nm}^{3}$ hydrogen $\left(\mathrm{H}_{2}\right)$. This leads to the demand of electric energy cheaper than coal to be able replacing the standard approved fossil fuels.

Besides biomass, biogenic waste gases can be converted to dimethyl ether [3]. Under biogenic waste gas, we understand land fill gas, biogas with a gas mixture of methane $\left(\mathrm{CH}_{4}\right)$, carbon dioxide $\left(\mathrm{CO}_{2}\right)$, nitrogen $\left(\mathrm{N}_{2}\right)$. In most cases the pollution of the biogenic waste gas are given by hydrogen sulfur (H2S), ammonia $\left(\mathrm{NH}_{3}\right)$, water. Before starting the conversion process the biogenic waste gas has to be cleaned free of hydrogen sulfur (H2S), ammonia $\left(\mathrm{NH}_{3}\right)$ and nitrogen $\left(\mathrm{N}_{2}\right)$. The conversion of methane $\left(\mathrm{CH}_{4}\right)$ and carbon dioxide $\left(\mathrm{CO}_{2}\right)$ can be done with a ATR (auto thermal reactor) to syngas with the gas mixture carbon monoxide (CO), hydrogen $\left(\mathrm{H}_{2}\right)$, carbon dioxide $\left(\mathrm{CO}_{2}\right)$ and water
$\left(\mathrm{H}_{2} \mathrm{O}\right)$. A small amount of methane $(\mathrm{CH} 4)$ is used to generate the needed heat and temperature in the reactor operating at $\mathrm{T}=800^{\circ} \mathrm{C}$. The partial oxygenation of methane $\left(\mathrm{CH}_{4}\right)$ is done by oxygen $\left(\mathrm{O}_{2}\right) \mathrm{CH}_{4}+2 \mathrm{O}_{2}=>\mathrm{CO}_{2}+2 \mathrm{H}_{2} \mathrm{O}$. Biogenic waste gases are limited in the same way as biomass is limited. Both resources are renewable but the landscape is the limiting factor, so we have to learn to find a solution using biogenic mass for living and waste for energy. This lowers the pressure on the renewable fresh growing biogenic mass and enables us to realize a recycling and sustainable conversion of biogenic waste.

Beside biogenic gases we can also convert flare gases [10] or shale gases [11] to dimethyl ether. The gas composition of flare gas is measured in the study [10] e.g. $80 \% \mathrm{H} 2,5 \% \mathrm{~N} 2,1 \% \mathrm{CO}_{2}, 1$ $\% \mathrm{CH}_{4}$. From this gas composition we see that it is a strong carbon dioxide sink in converting the flare gas to dimethyl ether. Gas preparing includes the known gas cleaning from dust and water and the separation of Nitrogen $\left(\mathrm{N}_{2}\right)$ and adding carbon dioxide $\left(\mathrm{CO}_{2}\right)$ to reach the molar gas mixture of carbon dioxide $\left(\mathrm{CO}_{2}\right)$ and hydrogen $\left(\mathrm{H}_{2}\right)$ by $1: 3$ is needed. The gas composition of Shale gas is measured in the study [11] e.g. $80 \% \mathrm{CH} 4,5 \% \mathrm{~N} 2,1 \% \mathrm{CO}_{2}, 1 \%$ H2. From this gas composition we see that it is a strong carbon dioxide sink again in converting the Shale gas to dimethyl ether. Gas preparing includes the known gas cleaning from dust and water and the separation of Nitrogen $\left(\mathrm{N}_{2}\right)$ and adding carbon dioxide $\left(\mathrm{CO}_{2}\right)$ to reach the molar gas mixture of carbon dioxide $\left(\mathrm{CO}_{2}\right)$ and hydrogen $\left(\mathrm{H}_{2}\right)$ by 1: 3 is needed. Both gas types flare gas and shale gas is parts of the fossil gas and oil production. We have to remember the fossil resources are also strong limited and not renewable as the renewable biomass, but because of the higher caloric heat value, the amount of fossil resources needed are twice time up to five time lower than the biogenic mass. This was the reason for changing to the fossil raw materials at the beginning of the 20th century. At the beginning of the 21th century we have rapidly to accept the mechanistic fossil time age is ending [12].

So for the production of dimethyl ether from carbon dioxide $\left(\mathrm{CO}_{2)}\right.$ and water $\left(\mathrm{H}_{2} \mathrm{O}\right)$ we need electric energy. This process can be up scaled based on the availability of electric energy. But on the thermodynamic side of view it does not make sense to use fossil resources to generate electric energy. This leads directly to increasing the amount of carbon dioxide. So if we look for other energy sources we think on renewable energy. But besides water power plants, solar power energy and wind power energy are weak energy processes and volatile and cannot be used as a local base load operation power plant. The last resource we have is nuclear power. If we focus on nuclear power, we are not interested in the low efficient processes using Uranium or Plutonium and the highly radioactive waste, we are interested in nuclear power based on a combination of the fission type and the fusion type. Following up the argumentation of [13] we are searching for a combination of fusion - fission hybrid nuclear power plant [14], mobile, small, compact, robust, stable in the 
power range of $5 \mathrm{MW}$ ele output and a high rate of regeneration of the used nuclear fuel. The electric power of $5 \mathrm{MWh}$ ele enables to produce at least $900 \mathrm{Nm}^{3} / \mathrm{h}$ hydrogen $\left(\mathrm{H}_{2}\right)$ which can be converted in combination with carbon dioxide $\left(\mathrm{CO}_{2}\right)$ to dimethyl ether. Beside the electric power we gain needed heat for the separation of the condensate mixture of dimethyl ether, water and methanol. Such nuclear power hybrids $[13,15]$ provide the conversion process of carbon dioxide $\left(\mathrm{CO}_{2}\right)$ and water $\left(\mathrm{H}_{2} \mathrm{O}\right)$ to Dimethyl ether with the needed electric energy, realizing a real and strong carbon dioxide sink.

In the first step we can use molten salt reactor technology in types of liquid Thorium molten salt reactors (Th $232+\mathrm{n}=>$ Th $233=>P a 233=>U 233+2 \mathrm{n}$ ) as a possible fission cycle. The idea of molten salt reactors is not new $[16,17]$. It is the direct consequent development of the ideas of E. Fermi [16] by Wigner E [17] and the technical realization by using a combination of molten salts (Lithium fluoride (LiF) and Beryllium Fluoride $\left(\mathrm{BeF}_{2}\right)$ ) instead of water $[16,17]$. But also the idea of fusion is not new $[18,19]$ But what we are searching is the combination of fission and fusion types regenerating and recycling nuclear fuel as proposed by [15] reducing the nuclear waste and regenerating a part of the nuclear fuel [20].

Nuclear power is one possibility in closing the need of electric energy by conversion of carbon dioxide $\left(\mathrm{CO}_{2}\right)$ and water $\left(\mathrm{H}_{2} \mathrm{O}\right)$. The nuclear fuel has a the property of a higher caloric value than the fossil resources like coal, gas or oil having a higher caloric heat value of biogenic mass and gases. The electric power gained by the fusion fission hybrids is large and carbon dioxide free. In combination with biogenic waste the production of dimethyl ether can be up scaled in an real production scale to support the rural economy, the transportation, to reduce the emission of carbon dioxide $\left(\mathrm{CO}_{2}\right)$ as GHG under very cost effective solution and to substitute fossil Diesel as a cheaper highly efficient fuel. If only biogenic waste or waste gases are available dimethyl ether can also be produced but with a limited scale [8]. In all application dimethyl ether has the property of a local and rural fuel supporting the development to reach zero emission, to enable a real carbon dioxide sink and to support agriculture and economy based on heavy machines.

\section{References}

1. (2015) NIST Chemistry Webbook, database 69.

2. (1999) Dimethyl ether as Diesel substitute (study). AVL List, Graz, Styria, Australia.

3. Angelidaki I, Karakashev D (2012) Alternative energy carriers for the transportation sector. DTU Environment.

4. Grezsler A (2012) Dimethyl ether from Natural Gas or Biomass: A Better Fuel Alternative. SAE International.

5. James P Szybist, Samuel McLaughlin, Suresh Iyer (2014) Emissions and Performance Benchmarking of a Prototype Dimethyl Ether-Fueled Heavy-Duty Truck. pp. 1-56.

6. Schwietzke S, Ladisch M, Russo L, Kwant K, Makinem T, et al. (2008) Analysis and Identification of gaps in Research for the production of second generation liquid transportation biofuels. IEA Bioenergy, pp. $1-20$.

7. Knoef HM (2005) Handbook of Gasification. BTG Biomass technology group, Netherlands.

8. Liu K, Song C, Subramani V (2010) Hydrogen and Syngas Production and Purification Technologies. Wiley Press.

9. Probstein R, Hicks RE (1982) Synthetic Fuels. Dover Publication, USA.

10. Caico CA (2003) Draft Flare Gas Flow Rate and composition Measurement. Shell.

11. (2015) Shale gas Handbook. ( $2^{\text {nd }}$ edn), A Norton Rose Fulbright guide, pp. 1-152.

12. Bethe HA (1996) Selected works. World Scientific, Singapore.

13. Fermi E (1950) Nuclear Physics. Chickago Press, USA.

14. Bethe HA (1959) The fission fusion Hybride.

15. Hargraves R (2013) Thorium energy cheaper than coal.

16. Wigner EP (1997) Collected works, Part A. Springer Press, USA.

17. Graeves ED, Furukawa K, Sajo-Bohus L, Barros H (2012) The case for the Thorium Molten Salt Reactor. Amer Inst o Phys.

18. LeBlanc D (2010) Molten Salt Reactors, Nuclear Engineering.

19. Ragheb M (2013) Fission Fusion Thorium Hybride, Nuclear Technology.

20. Eddington A (1926) The internal constitution of the star. Cambridge University Press, India.

Your next submission with Juniper Publishers will reach you the below assets

- Quality Editorial service

- Swift Peer Review

- Reprints availability

- E-prints Service

- Manuscript Podcast for convenient understanding

- Global attainment for your research

- Manuscript accessibility in different formats

( Pdf, E-pub, Full Text, Audio)

- Unceasing customer service

Track the below URL for one-step submission

https://juniperpublishers.com/online-submission.php 